Sādhanā Vol. 39, Part 5, October 2014, pp. 1055-1070. (C) Indian Academy of Sciences

\title{
Application of Taguchi method for cutting force optimization in rock sawing by circular diamond sawblades
}

\author{
IZZET KARAKURT \\ Department of Mining Engineering, Karadeniz Technical University, \\ Trabzon 61080, Turkey \\ e-mail: karakurt@ktu.edu.tr
}

MS received 29 March 2013; revised 15 January 2014; accepted 21 April 2014

\begin{abstract}
In this paper, an optimization study was carried out for the cutting force $\left(\mathrm{F}_{\mathrm{c}}\right)$ acting on circular diamond sawblades in rock sawing. The peripheral speed, traverse speed, cut depth and flow rate of cooling fluid were considered as operating variables and optimized by using Taguchi approach for the $\mathrm{F}_{\mathrm{c}} \cdot \mathrm{L}_{16}\left(4^{4}\right)$ orthogonal array was chosen for the experimental trials based on the operating variables and their levels. The signal-to-noise $(\mathrm{S} / \mathrm{N})$ ratios and the analysis of variance (ANOVA) were employed to determine optimum cutting conditions and significant operating variables, respectively. The $\mathrm{F}_{c}$ was also modelled based on the operating variables using regression analysis. The developed model was then verified using various statistical approaches. The results revealed that the operating variables of circular diamond sawblades can be precisely optimized by Taguchi approach for the $\mathrm{F}_{c}$ in rock sawing. The cut depth and peripheral speed were statistically determined as the significant operating variables affecting $\mathrm{F}_{c}$. Furthermore, the modelling results showed that the proposed model can be effectively used for the prediction of $\mathrm{F}_{c}$ in practical applications.
\end{abstract}

Keywords. Rock sawing; cutting force; Taguchi application; optimization; modelling.

\section{Introduction}

The use of natural stones as a construction and building material has been increasing worldwide. As a result of this increase, there has been recently more attention for sustainability during their productions (Karakurt et al 2012). Circular diamond sawblades have been successfully used in sawing of almost all types of natural stones due to their distinctive advantages over other traditional cutting tools (Ersoy et al 2005).

As in the case of other machining tools, the cutting performances of circular diamond sawblades are affected by the complex interaction of many effective parameters as given in table 1 (Yousefi et al 2010). Despite these parameters affecting the cutting performances, circular diamond sawblades have been subjected to various studies in the existing literature. These studies can be mainly grouped as sawing mechanisms, saw design, relationships between sawability and rock properties. Kahraman \& Gunaydin (2008), Atıcı \& Ersoy (2009), Aslantas et al (2009), 
Table 1. Effective parameters in sawing process.

\begin{tabular}{|c|c|c|c|}
\hline \multicolumn{2}{|c|}{$\begin{array}{l}\text { Non-controlled parameters related to the } \\
\text { rock characteristics }\end{array}$} & \multicolumn{2}{|c|}{$\begin{array}{l}\text { Partially controlled or controlled } \\
\text { parameters }\end{array}$} \\
\hline Mechanical properties & $\begin{array}{l}\text { Uniaxial compressive strength } \\
\text { Tensile strength } \\
\text { Bending strength } \\
\text { Young's modulus } \\
\text { Hardness } \\
\text { Abrasiveness } \\
\text { Water content }\end{array}$ & Sawing characteristics & $\begin{array}{l}\text { Force on saw } \\
\text { Traverse speed } \\
\text { Specific removal rate } \\
\text { Peripheral speed } \\
\text { Depth of cut } \\
\text { Specific energy } \\
\text { Cutting mode }\end{array}$ \\
\hline \multirow[t]{2}{*}{ Textural properties } & $\begin{array}{l}\text { Grain size } \\
\text { Grain shape } \\
\text { Mineral type and content } \\
\text { Degree and type of cementation } \\
\text { Bonding }\end{array}$ & Saw design & $\begin{array}{l}\text { Diamond properties } \\
\text { Matrix properties } \\
\text { Machine vibration } \\
\text { Operator skill }\end{array}$ \\
\hline & Matrix type and content & Working conditions & $\begin{array}{l}\text { Machine power } \\
\text { Amount of water used }\end{array}$ \\
\hline Structural properties & $\begin{array}{l}\text { Joints and fractures } \\
\text { Degree of alteration } \\
\text { Cleavages }\end{array}$ & & Environment / climate \\
\hline
\end{tabular}

Buyuksagis (2010), Yousefi et al (2010), Guney (2011), Mikaeil et al (2011, 2013), Y1lmaz et al (2011), Y1lmaz (2011), Ucun et al (2011), Ataei et al (2012), Yaşıtlı et al (2012), Turchetta (2012), Aydin et al (2013a, b, c), Engin et al (2013), Bayram (2013), Karakurt et al (2013a, b) and Sengun \& Altindag (2013) are among the most recently published papers in the existing literature. The studies indicate that the cutting performances of circular sawblades have been well-documented. However, further studies aiming at establishing standards for the cutting performances of circular diamond sawblades in rock sawing are still required due to the complex nature of the rock material. On the other hand, stone producers want to know the sawability degree of a particular rock being cut for the cost estimation and planning of the plants. Thus, selection of suitable operating variables and proper sawing result can decrease in the production costs and can increase in productivity. Therefore, it is highly important to optimize the sawing processes for improving the productivity and decreasing the production costs. Additionally, although it has been successfully used for determination of the optimum operating variables in various industries, no application of the Taguchi method in rock sawing by circular diamond sawblades has been reported so far. Therefore, an optimization study for the $\mathrm{F}_{c}$ acting on diamond sawblades in rock sawing using Taguchi approach is presented in this study. The study mainly aims at applying the Taguchi method for the determination of optimum operating variables to minimize the $\mathrm{F}_{c}$ affecting directly the tool wear, cutting temperatures, and surface integrity in sawing processes. A predictive model for the $\mathrm{F}_{c}$ is also proposed using regression analysis based on the operating variables.

\section{The Taguchi methodology}

Statistical experimental design methods provide a systematic and efficient plans for experimentation to achieve certain goals so that many control factors can be simultaneously studied. 
Taguchi's approach is totally associated with the statistical design of experiments. The Taguchi method, established by Genichi Taguchi has been generally adopted to optimize the design variables since this method can significantly reduce the overall testing time and the costs (Wang \& Huang 2007). Three major tools which are used in the Taguchi method are the orthogonal arrays (OA's), analysis of variance (ANOVA) and the signal $(\mathrm{S})$ to noise $(\mathrm{N})$ ratios (S/Ns). Taguchi method utilizes OA's from experimental design theory to study a large number of variables with a small number of experiments. An OA consists of rows and columns. Each column of the OA represents a variable assigned, while each row of the OA represents a run or level of the variables to be applied (Nik et al 2012). Depending on the number of variables and levels required,

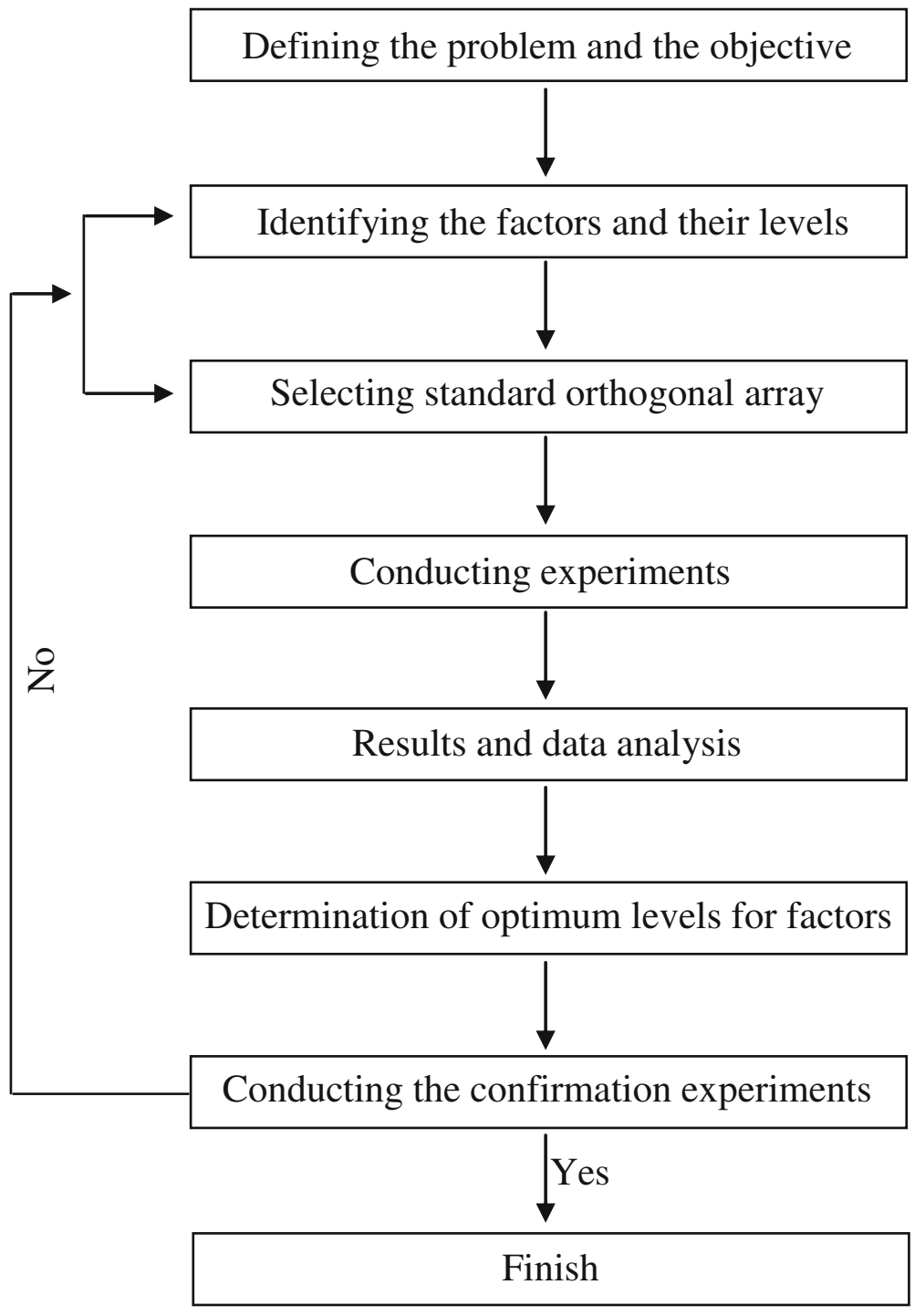

Figure 1. A flowchart of the Taguchi application. 
the users can select the standard orthogonal arrays designed specifically and conduct the experiments. On the other hand, ANOVA is a matrix of numbers arranged in rows and columns. Each row represents the levels of variable in each run and each column represents a specific level for a variable that can be arranged for each run (Adnani et al 2010). The $\mathrm{S} / \mathrm{N}$ ratios are a useful concept to characterize the response of any particular engineering system to external influences. In other words, ANOVA and the S/N ratios are used to evaluate the experimental results. A flowchart of the Taguchi application for the optimization studies is presented in figure 1. The $\mathrm{S} / \mathrm{N}$ ratios can be divided into three categories as shown below when the characteristic is continuous: (1) nominal is the best (NB), (2) smaller is the better (SB), (3) larger is the better (LB) (Ghani et al 2004).

$$
\begin{aligned}
& \text { Nominal is the best: } S / N s=10 \log \frac{\bar{y}}{s_{y}^{2}}, \\
& \text { Smaller is the best: } S / N s=-10 \log \frac{1}{n}\left(\sum y^{2}\right), \\
& \text { Larger is the best: } S / N s=-10 \log \frac{1}{n}\left(\sum \frac{1}{y^{2}}\right),
\end{aligned}
$$

where $\bar{y}$ is the average observed data, $s_{y}^{2}$ is the variance of $y, n$ is the number of observations, and $y$ is the observed data. In all cases, the higher the $\mathrm{S} / \mathrm{N}$ ratio, the better is the result.

\section{Experimental study}

\subsection{Material}

In this study, a pre-dimensioned granitic rock was used for the sawing experiments. Each rock sample has a thickness of $3 \mathrm{~cm}$, length of $30 \mathrm{~cm}$ and width of $10 \mathrm{~cm}$. The mineralogical and petrographical properties of the sample were determined through thin section studies and the point-count method (see figure 2). The mineralogical compositions of the rock are given in table 2 along with its textural and granular descriptions. As can be followed from table 2, $\mathrm{K}$-feldspar, quartz, plagioclase and biotite are the main rock-forming minerals of the used rock. Additionally, grain size distribution of the rock-forming minerals was also determined using digital image processing software of DeWinter Material Plus 4.1. Some physico-mechanical properties of the tested rock were determined according to the related ISRM (1981) suggested methods (see table 3 ).
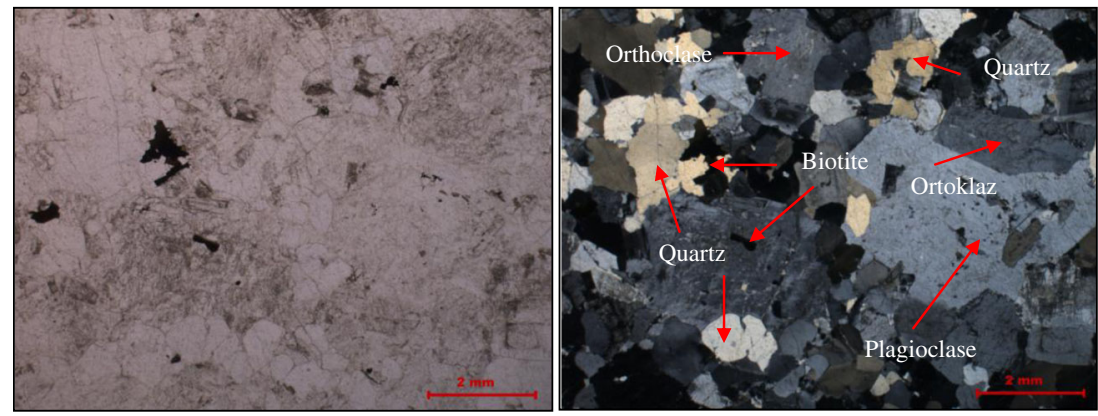

Figure 2. Thin section studies of the tested rock. 
Table 2. Mineralogical and petrographic description of the rock used in the experiments.

\begin{tabular}{lllcc}
\hline \multirow{2}{*}{ Mineral } & \multicolumn{3}{c}{ Grain size $(\mathrm{mm})$} & Proportion (\%) \\
\cline { 2 - 4 } Alkali feldspars (orthoclase. microcline) & 0.48 & 4.80 & 0.8 & 39 \\
Quartz & 0.24 & 2.24 & 1.7 & 27 \\
Plagioclase & 0.56 & 3.60 & 2.0 & 22 \\
Biotite & 0.32 & 1.60 & 0.4 & 10 \\
Secondary components & 0.08 & 0.56 & 2 \\
Petrographic descriptions & Rock name: Alkali granite. Granular, hypidiomorphic \\
& texture, coarse-grained, grains between 0.08 mm and $4.80 \mathrm{~mm}$, \\
& and the coarsest grain is observed in alkali \\
& feldspar mineral. Alkali feldspar, quartz and \\
& plagioclase are the predominant minerals, opaque \\
& minerals are the accessories, small amount of biotite is \\
& observed. Alkali feldpars have perthitic texture and \\
& altered to clay. Typically showing twinning, \\
& microcline minerals altered to clay. Anhedral quartz, \\
& plagioclase show polysynthetic twinning, they are \\
& prizmatic and slightly altered to clay. \\
\hline
\end{tabular}

\subsection{Experimental design}

Once the problems and objectives of the study are defined, the next two steps include the determination of the operating variables and their levels that influence the performance characteristics and conducting the experiments in the design of philosophy of Taguchi. Therefore, a total of four operating variables, each varied at four levels was selected in the current study. These operating variables are the peripheral speed, the traverse speed, the cut depth and the flow rate of cooling fluid. Their levels were selected based on preliminary sawing tests by considering instructions of diamond disc manufacturers and related literatures. Tap water was used as the cutting fluid. The selected operating variables and their levels are given in table 4. Based on the operating variables and their levels, a standard orthogonal array of $\mathrm{L}_{16}\left(4^{4}\right)$ was found to be appropriate for the experimental layout which requires 16 trials (see table 5). $\mathrm{S} / \mathrm{N}$ ratios which are a statistical measure of performance in Taguchi method was subsequently used to analyse the results.

Table 3. Physico-mechanical properties of the rock used in the experiments.

\begin{tabular}{lc}
\hline Rock properties & Value \\
\hline Density $\left(\mathrm{kN} / \mathrm{m}^{3}\right)$ & 25.9 \\
Water absorption by volume (\%) & 0.86 \\
Porosity $(\%)$ & 1.50 \\
Ultrasonic velocity (m/s) & 4140 \\
Cerchar abrasion Index & 5.2 \\
Schmidt hammer hardness & 56 \\
Microhardness (HV) & 539.55 \\
Shore hardness & 75.6 \\
Mohs hardness scale & 4.5 \\
\hline
\end{tabular}


Table 4. Operating variables and their levels used in the experimentations.

\begin{tabular}{lccccc}
\hline Operating variables & Symbol & \multicolumn{3}{c}{ Level } \\
\hline Peripheral speed (m/s) & A & 25 & 30 & 35 & 40 \\
Traverse speed $(\mathrm{cm} / \mathrm{min})$ & B & 40 & 50 & 60 & 70 \\
Cutting depth $(\mathrm{cm})$ & C & 0.5 & 1.0 & 1.5 & 2.0 \\
Flow rate of cooling fluid $(\mathrm{ml} / \mathrm{s})$ & D & 50 & 100 & 150 & 200 \\
\hline
\end{tabular}

Here, the term signal (S) represents desirable value (mean), and noise $(\mathrm{N})$ represents undesirable value (standard deviation from mean) for the results. Specifically, the smaller and the better characteristics form for $\mathrm{S} / \mathrm{N}$ were selected since the lower values of cutting force were desired in sawing applications. The $\mathrm{S} / \mathrm{N}$ ratios of the smaller the better performance characteristic were then calculated thorough the equation below using MiniTAB statistical software.

$$
S / N s=-10 \log \frac{1}{n}\left(\sum y^{2}\right),
$$

where $n$ is the number of tests, $y$ is the observed data.

\subsection{Experimental set-up}

A computer-aided circular diamond sawblades were used for sawing experimentations as shown in figure 3. The circular diamond sawblades consist of three major sub-systems: a cutting unit, instrumentation and a personal computer (PC). The diamond sawblade used in the tests was of $40 \mathrm{~cm}$ diameter, having 28 impregnated diamond segments (circumferential length $40 \mathrm{~mm}$, width $3.5 \mathrm{~mm}$ and height $10 \mathrm{~mm}$ ). The diamonds were sized at 40/50 US mesh with a concentration of 30 which is recommended for the sawing of hard materials. Sawblade movements,

Table 5. Experimental layout for $\mathrm{L}_{16}\left(4^{4}\right)$ orthogonal array including the operating variables.

\begin{tabular}{llcccc}
\hline & & \multicolumn{4}{c}{ Operating variables } \\
\cline { 3 - 6 } Trials & $\begin{array}{c}\mathrm{A} \\
(\mathrm{m} / \mathrm{s})\end{array}$ & $\begin{array}{c}\mathrm{B} \\
(\mathrm{cm} / \mathrm{min})\end{array}$ & $\begin{array}{c}\mathrm{C} \\
(\mathrm{cm})\end{array}$ & $\begin{array}{c}\mathrm{D} \\
(\mathrm{ml} / \mathrm{s})\end{array}$ \\
\hline 1 & Designation & 1 & 1 & 1 & 1 \\
2 & $\mathrm{~A}_{1} \mathrm{~B}_{1} \mathrm{C}_{1} \mathrm{D}_{1}$ & 1 & 2 & 2 & 2 \\
3 & $\mathrm{~A}_{1} \mathrm{~B}_{2} \mathrm{C}_{2} \mathrm{D}_{2}$ & 1 & 3 & 3 & 3 \\
4 & $\mathrm{~A}_{1} \mathrm{~B}_{3} \mathrm{C}_{3} \mathrm{D}_{3}$ & 1 & 4 & 4 & 4 \\
5 & $\mathrm{~A}_{1} \mathrm{~B}_{4} \mathrm{C}_{4} \mathrm{D}_{4}$ & 1 & 1 & 2 & 3 \\
6 & $\mathrm{~A}_{2} \mathrm{~B}_{1} \mathrm{C}_{2} \mathrm{D}_{3}$ & 2 & 2 & 1 & 4 \\
7 & $\mathrm{~A}_{2} \mathrm{~B}_{2} \mathrm{C}_{1} \mathrm{D}_{4}$ & 2 & 3 & 4 & 1 \\
8 & $\mathrm{~A}_{2} \mathrm{~B}_{3} \mathrm{C}_{4} \mathrm{D}_{1}$ & 2 & 4 & 3 & 2 \\
9 & $\mathrm{~A}_{2} \mathrm{~B}_{4} \mathrm{C}_{3} \mathrm{D}_{2}$ & 2 & 1 & 3 & 4 \\
10 & $\mathrm{~A}_{3} \mathrm{~B}_{1} \mathrm{C}_{3} \mathrm{D}_{4}$ & 3 & 3 & 4 & 3 \\
11 & $\mathrm{~A}_{3} \mathrm{~B}_{2} \mathrm{C}_{4} \mathrm{D}_{3}$ & 3 & 4 & 2 & 1 \\
12 & $\mathrm{~A}_{3} \mathrm{~B}_{3} \mathrm{C}_{1} \mathrm{D}_{2}$ & 3 & 1 & 4 & 2 \\
13 & $\mathrm{~A}_{3} \mathrm{~B}_{4} \mathrm{C}_{2} \mathrm{D}_{1}$ & 3 & 2 & 3 & 1 \\
14 & $\mathrm{~A}_{4} \mathrm{~B}_{1} \mathrm{C}_{4} \mathrm{D}_{2}$ & 4 & 3 & 2 & 4 \\
15 & $\mathrm{~A}_{4} \mathrm{~B}_{2} \mathrm{C}_{3} \mathrm{D}_{1}$ & 4 & 4 & 1 & 3 \\
16 & $\mathrm{~A}_{4} \mathrm{~B}_{3} \mathrm{C}_{2} \mathrm{D}_{4}$ & 4 & 4 & & 2 \\
\hline
\end{tabular}




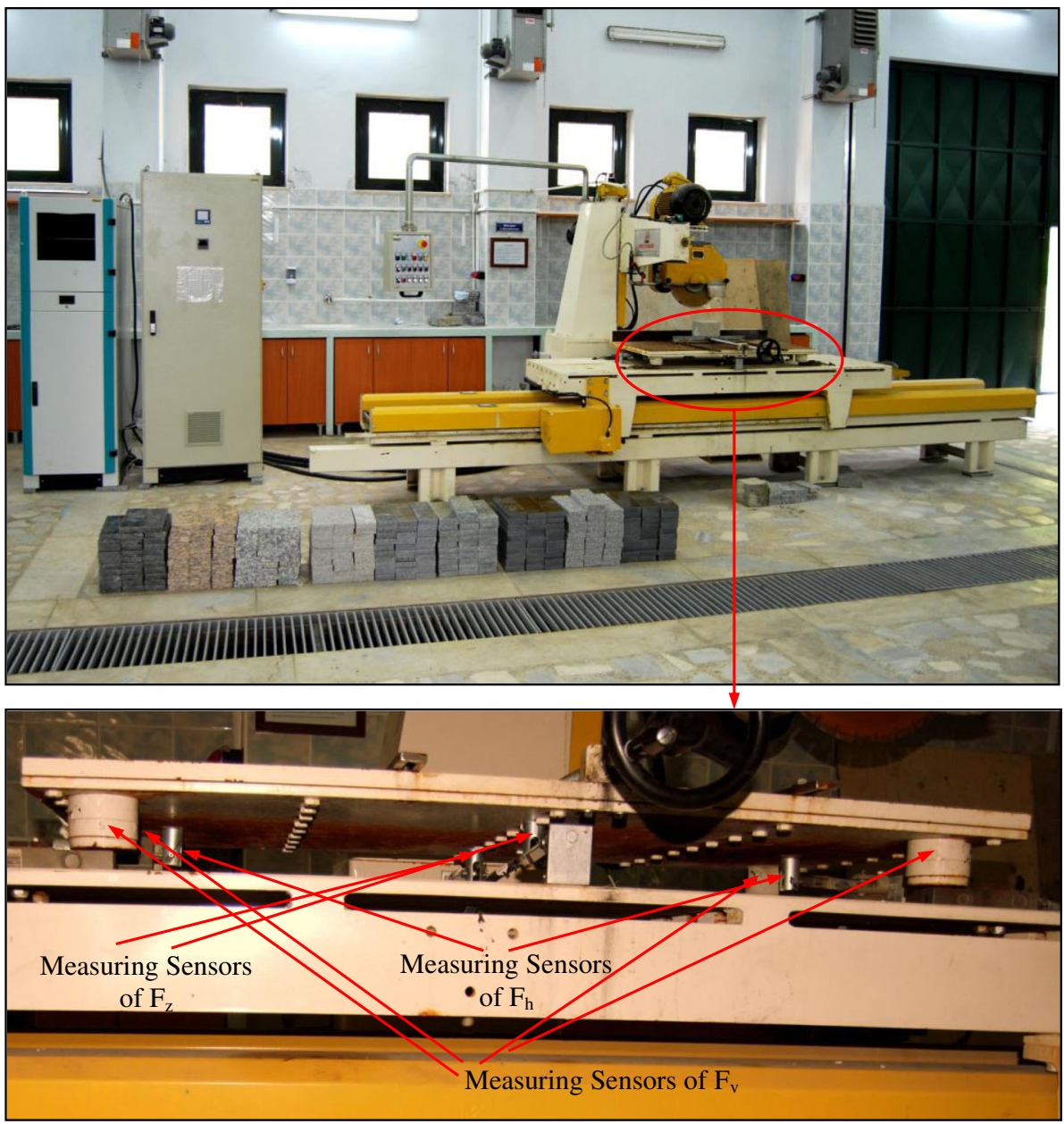

Figure 3. A view of circular diamond sawblades used for the experimentations.

forward-backward in the horizontal plane and up-down in the vertical plane, were driven with two $0.75 \mathrm{~kW}$ ac motors, while the turn of the disc were driven with $4 \mathrm{~kW}$ ac motor. Moreover, $0.75 \mathrm{~kW}$ ac motor was used to move the wagon through the cutting line. Operating variables, vertical, horizontal, and axial forces were measured using sensors, load cells, transducers and an encoder in the monitoring system. The force measuring sensors were modelled as SBS $500 \mathrm{~kg}$ C3 and STCS $100 \mathrm{~kg} \mathrm{C3}$ for vertical, horizontal and axial forces, respectively. The accuracy of the measured forces from those force sensors is $\pm 0.01 \mathrm{~kg}$. All movements of the cutting tools were controlled by the computer and industrial electronic cards. Transmissions to the computer were carried out using processing software.

\subsection{Experimental procedure}

The diamond sawblade was firstly dressed by cutting a siliceous sedimentary tuff block before the cutting tests. Afterwards, the sawing experiments were conducted. The rock sample was subjected to saw through its length. Due to the variability and accuracy of the experimental 
data, the sample was sawn four times at the same conditions. All cutting experiments were conducted in the down-cutting mode. The horizontal $\left(\mathrm{F}_{h}\right)$ and vertical $\left(\mathrm{F}_{v}\right)$ force components acting on the disc were measured using load cells. The tangential $\left(\mathrm{F}_{t}\right)$ and normal $\left(\mathrm{F}_{n}\right)$ force were derived from the Eqs. (6-16) considering the geometrical relations presented in figure 4 (Konstanty 2002; Tönshoff \& Apmann 2002).

$$
\begin{gathered}
\operatorname{Cos} \delta=\frac{\mathrm{F}_{\mathrm{v}}}{\mathrm{F}_{\mathrm{c}}}, \\
\operatorname{Sin} \delta=\frac{\mathrm{F}_{\mathrm{h}}}{\mathrm{F}_{\mathrm{c}}} \\
\mathrm{F}_{\mathrm{n}}=\mathrm{F}_{\mathrm{c}} \operatorname{Cos}[(\mathrm{k} \varphi)-\delta], \\
F_{n}=F_{c}\left[\operatorname{Cos}(k \phi) \frac{F_{v}}{F_{c}}+\operatorname{Sin}(k \phi) \frac{F_{v}}{F_{c}}\right], \\
\mathrm{F}_{\mathrm{n}}=\mathrm{F}_{\mathrm{v}} \operatorname{Cos}(\mathrm{k} \varphi)+\mathrm{F}_{\mathrm{h}} \operatorname{Sin}(\mathrm{k} \varphi), \\
\mathrm{F}_{\mathrm{t}}=\mathrm{F}_{\mathrm{c}} \operatorname{Sin}[(\mathrm{k} \varphi)-\delta], \\
F_{t}=F_{c}\left[\operatorname{Sin}(k \phi) \frac{F_{v}}{F_{c}}-\operatorname{Cos}(k \phi) \frac{F_{h}}{F_{c}}\right], \\
\mathrm{F}_{\mathrm{t}}=\mathrm{F}_{\mathrm{v}} \operatorname{Sin}(\mathrm{k} \varphi)-\mathrm{F}_{\mathrm{h}} \operatorname{Cos}(\mathrm{k} \varphi), \\
\mathrm{F}_{\mathrm{c}}=\sqrt{\mathrm{F}_{\mathrm{n}}^{2}+\mathrm{F}_{\mathrm{t}}^{2}},
\end{gathered}
$$

where: $\mathrm{F}_{h}$; the horizontal force $(\mathrm{N}), \mathrm{F}_{v}$; the vertical force $(\mathrm{N}), \mathrm{F}_{z}$; the axial force $(\mathrm{N}), \mathrm{F}_{n}$; the normal force $(\mathrm{N}), \mathrm{F}_{t}$; the tangential force $(\mathrm{N}), \mathrm{F}_{c}$; the resultant cutting force $(\mathrm{N}), \mathrm{D}_{s}$; the disc diameter $(\mathrm{mm}), \mathrm{d}$; the cutting depth $(\mathrm{mm}), \mathrm{V}_{c}$; the workpiece traverse speed $(\mathrm{m} / \mathrm{s}), \mathrm{V}_{p}$; the peripheral speed $(\mathrm{m} / \mathrm{s}), \varphi$; the total included angle of the contact zone (degrees) and $\mathrm{k} \varphi$; is the angle showing the location of the resultant force (degrees). The total included angle of the contact

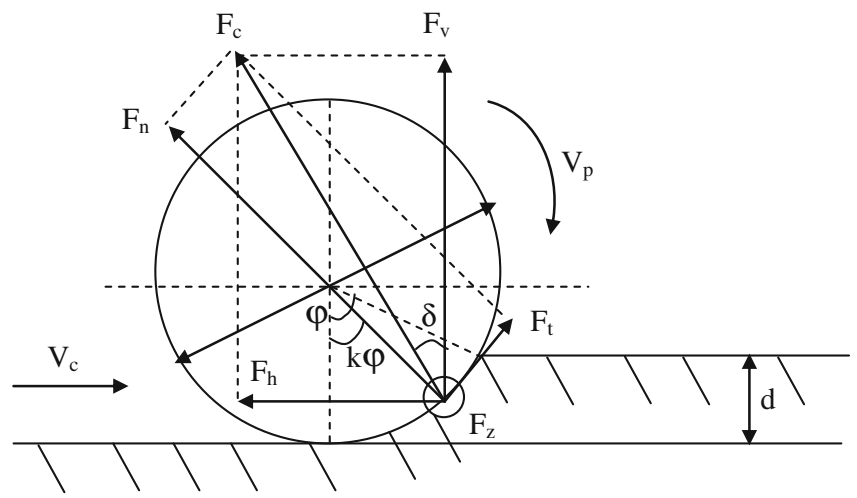

Figure 4. The kinematics of cutting process for the down-cutting model. 
zone $(\varphi)$ and the angle $(\mathrm{k} \varphi)$ indicating the location of the resultant force can be calculated by the following equations:

$$
\begin{gathered}
\varphi=\cos ^{-1}\left(1-\frac{2 \mathrm{~d}}{\mathrm{D}_{\mathrm{s}}}\right), \\
\mathrm{k} \varphi=0.7 \varphi .
\end{gathered}
$$

\subsection{Optimization studies}

Analysi s of mean (ANOM) approach was adopted to develop the optimum conditions. The mean of the $\mathrm{S} / \mathrm{N}$ ratios of each factor at a certain level can be calculated using the equation below(Chou et al 2010).

$$
(M)_{\text {Factor }=l}^{\text {Level }=i}=\frac{1}{n_{l i}} \sum_{j=1}^{n_{l i}}\left[\left(\frac{S}{N}\right)_{\text {Factor }=l}^{\text {Level }=i}\right]_{j},
$$

where $n_{l i}$ is the number of appearances of factor $I$ in the level $i$, and $\left[(\mathrm{S} / \mathrm{N}) \text { factor }{ }^{\text {Level }}=i=I\right]_{j}$ is the $\mathrm{S} / \mathrm{N}$ ratio of factor $I$ in level $i$, and its appearance sequence in table is the $j t h$. Thus, the $\mathrm{S} / \mathrm{N}$ response was obtained together with the optimum conditions. Additionally, to define which operating variables significantly affect the quality characteristic, analysis of variance (ANOVA) was done. Finally, confirmation experiments under these optimum conditions were conducted.

\section{Results and data analysis}

\subsection{Optimum conditions}

The performance of circular diamond sawblades was evaluated for $\mathrm{F}_{c}$ with respect to the Eq. (14) and the results presented in table 6 . Afterwards, the $\mathrm{S} / \mathrm{N}$ ratios were then calculated. The maximum values of $\mathrm{S} / \mathrm{N}$ ratios among the 16 trials were determined. ANOM was then produced

Table 6. Experimental results including the operating variables, their levels, results and S/N ratios.

\begin{tabular}{lccccccc}
\hline Trials & $\begin{array}{c}\mathrm{A} \\
(\mathrm{m} / \mathrm{s})\end{array}$ & $\begin{array}{c}\mathrm{B} \\
(\mathrm{cm} / \mathrm{min})\end{array}$ & $\begin{array}{c}\mathrm{C} \\
(\mathrm{cm})\end{array}$ & $\begin{array}{c}\mathrm{D} \\
(\mathrm{ml} / \mathrm{s})\end{array}$ & $\mathrm{F}_{\mathrm{c}}(\mathrm{N})$ & $\begin{array}{c}\text { Standard } \\
\text { deviation }\end{array}$ & S/N ratios \\
\hline 1 & 25 & 40 & 0.5 & 50 & 67.95 & 2.41 & $-36,64$ \\
2 & 25 & 50 & 1.0 & 100 & 132.20 & 4.80 & -42.42 \\
3 & 25 & 60 & 1.5 & 150 & 179.20 & 3.31 & -45.07 \\
4 & 25 & 70 & 2.0 & 200 & 212.81 & 5.88 & -46.56 \\
5 & 30 & 40 & 1.0 & 150 & 89.58 & 1.17 & -39.04 \\
6 & 30 & 50 & 0.5 & 200 & 55.99 & 1.36 & -34.96 \\
7 & 30 & 60 & 2.0 & 50 & 214.82 & 6.22 & -46.64 \\
8 & 30 & 70 & 1.5 & 100 & 151.36 & 5.37 & -43.60 \\
9 & 35 & 40 & 1.5 & 200 & 90.81 & 1.73 & -39.16 \\
10 & 35 & 50 & 2.0 & 150 & 123.81 & 2.72 & -41.86 \\
11 & 35 & 60 & 0.5 & 100 & 68.98 & 1.79 & -36.77 \\
12 & 35 & 70 & 1.0 & 50 & 133.77 & 3.01 & -42.53 \\
13 & 40 & 40 & 2.0 & 100 & 117.34 & 1.62 & -41.39 \\
14 & 40 & 50 & 1.5 & 50 & 151.29 & 4.35 & -43.59 \\
15 & 40 & 60 & 1.0 & 200 & 71.15 & 1.33 & -37.04 \\
16 & 40 & 70 & 0.5 & 150 & 48.11 & 1.72 & $-33.65^{*}$ \\
\hline
\end{tabular}

* Indicates the maximum value of $\mathrm{S} / \mathrm{N}$ ratios among the 16 trials 
Table 7. $\mathrm{S} / \mathrm{N}$ ratio response table for $\mathrm{F}_{\mathrm{c}}$.

\begin{tabular}{lccccc}
\hline & \multicolumn{4}{c}{ S/N ratio } & \\
\cline { 2 - 4 } Factor/level & $j=1$ & $j=2$ & $j=3$ & $j=4$ & ANOM \\
\hline $\mathrm{A} / 1$ & -36.64 & -42.42 & -45.07 & -46.56 & -41.92 \\
$\mathrm{~A} / 2$ & -39.04 & -34.96 & -46.64 & -43.60 & -41.06 \\
$\mathrm{~A} / 3$ & -39.16 & -41.86 & -36.77 & -42.53 & -40.08 \\
$\mathrm{~A} / 4$ & -41.39 & -43.59 & -37.04 & -33.65 & $-38.92^{*}$ \\
$\mathrm{~B} / 1$ & -36.64 & -39.04 & -39.16 & -41.39 & $-39.06^{*}$ \\
$\mathrm{~B} / 2$ & -42.42 & -34.96 & -41.86 & -43.59 & -40.71 \\
$\mathrm{~B} / 3$ & -45.07 & -46.64 & -36.77 & -37.04 & -41.38 \\
$\mathrm{~B} / 4$ & -46.56 & -43.60 & -42.53 & -33.65 & -41.59 \\
$\mathrm{C} / 1$ & -36.64 & -34.96 & -36.77 & -33.65 & $-35.51^{*}$ \\
$\mathrm{C} / 2$ & -42.42 & -39.04 & -42.53 & -37.04 & -40.26 \\
$\mathrm{C} / 3$ & -45.07 & -43.60 & -39.16 & -43.59 & -42.86 \\
$\mathrm{C} / 4$ & -46.56 & -46.64 & -41.86 & -41.39 & -44.11 \\
$\mathrm{D} / 1$ & -36.64 & -46.64 & -42.53 & -43.59 & -42.35 \\
$\mathrm{D} / 2$ & -42.42 & -43.60 & -36.77 & -41.39 & -41.05 \\
$\mathrm{D} / 3$ & -45.07 & -39.04 & -41.86 & -33.65 & -39.91 \\
$\mathrm{D} / 4$ & -46.56 & -34.96 & -39.16 & -37.04 & $-39.43^{*}$ \\
\hline
\end{tabular}

* Indicates the maximum value of the mean of the $\mathrm{S} / \mathrm{N}$ ratios of a certain factor among the four levels

and given in table 7. Also, the maximum values of the mean of the $\mathrm{S} / \mathrm{N}$ ratios of a certain factor among the four levels were determined. These values refer to the optimum conditions for $\mathrm{F}_{c}$. Based on table 7, the optimum operating variables minimizing the $\mathrm{F}_{c}$ are the peripheral speed at level $4(40 \mathrm{~m} / \mathrm{s})$, the traverse speed at level $1(40 \mathrm{~cm} / \mathrm{min})$, the cut depth at level $1(0.5 \mathrm{~cm})$,

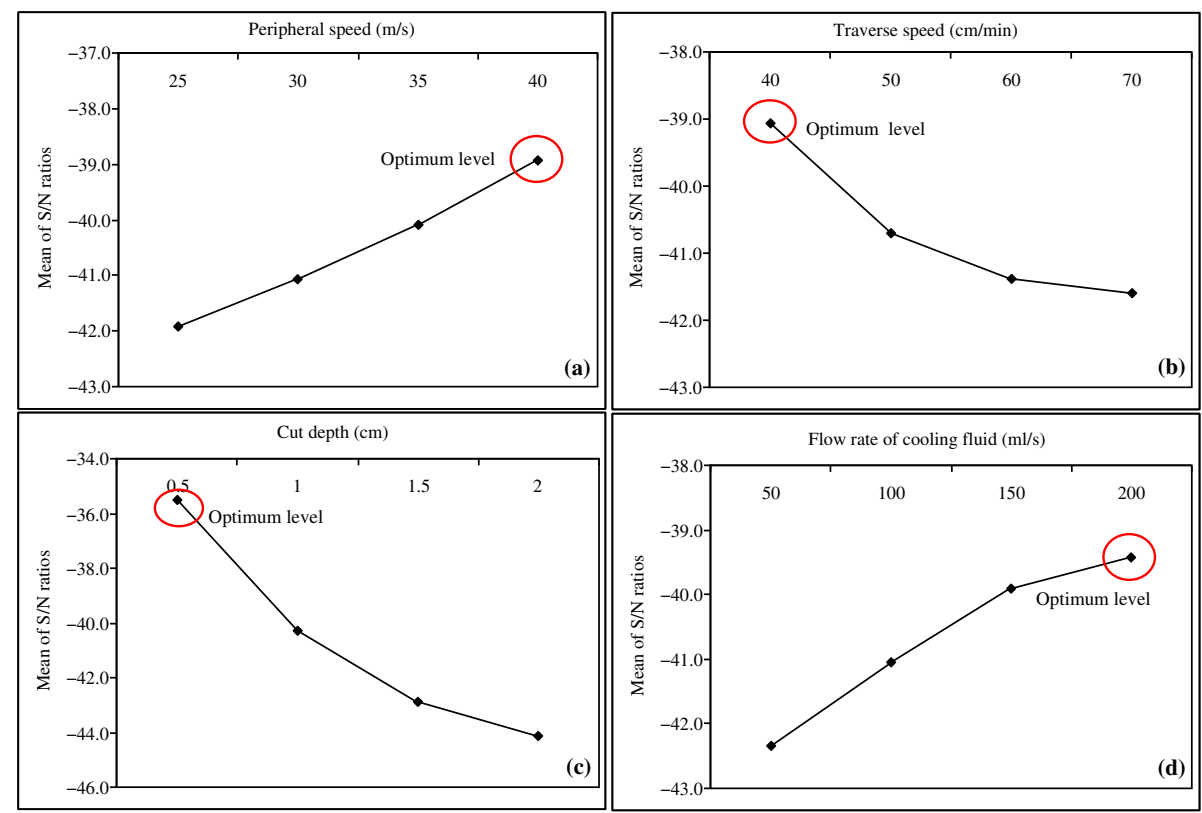

Figure 5. Effects of operating variables on the $\mathrm{S} / \mathrm{N}$ ratio for the specific energy. (a) peripheral speed, (b) traverse speed, (c) cut depth and (d) flow rate of cooling fluid. 
and the flow rate of cooling fluid at level $4(200 \mathrm{ml} / \mathrm{s})$. In this case, the designation for optimum operating variables was determined as $\mathrm{A}_{4} \mathrm{~B}_{1} \mathrm{C}_{1} \mathrm{D}_{4}$.

\subsection{Influence of operating variables on the $F_{c}$}

The graphical illustrations of the $\mathrm{S} / \mathrm{N}$ ratios are presented in figure 5. As shown, all variables have significant influences on the $\mathrm{F}_{c}$ but, their significance degrees vary. The cut depth, the peripheral speed and the flow rate of cooling fluid are more significant than the traverse speed has. The ANOVA analysis confirmed this observation as well (see table 8). The cut depth has the greatest influence on the $\mathrm{F}_{c}$ with the impact factor of $70.46 \%$, followed by the peripheral speed. When the traverse speed and the cut depth increases, the $\mathrm{F}_{c}$ increases almost proportionally. On the other hand, the highest levels for the peripheral speed and the flow rate of cooling fluid appear to be the best choice to obtain the minimum value of $\mathrm{F}_{c}$, whereas the lowest levels of the traverse speed and the cut depths appeared to be the optimum choices.

\subsection{Analysis of variance (ANOVA)}

An analysis of variance (ANOVA) of the experimental results was performed to evaluate the relative importance of the operating variables. This has been accomplished by separating the total variability of the $\mathrm{S} / \mathrm{N}$ ratios, which is measured by the sum of the squared deviations from the total mean of the $\mathrm{S} / \mathrm{N}$ ratios, into contributions by each of the operating variables and the errors. The total sum of squared deviations $S S_{T}$ from the total mean $\mathrm{S} / \mathrm{N}$ ratios can be calculated as

$$
S S_{T}=\sum_{i=1}^{n}\left(n_{i}-n_{m}\right)^{2},
$$

where $n$ is the number of experiments in the orthogonal array and $n_{i}$ is the mean of $\mathrm{S} / \mathrm{N}$ ratios for the ith experiment. The total sum of spared deviations $\mathrm{SS}_{T}$ is decomposed into two sources: the sum of squared deviations $\mathrm{SS}_{d}$ due to each design parameter and the sum of squared error $\mathrm{SS}_{e}$. The percentage contribution (\%) can be then calculated as

$$
\mathrm{C}(\%)=\frac{\mathrm{SS}_{\mathrm{d}}}{\mathrm{SS}_{\mathrm{T}}}
$$

where $\mathrm{SS}_{d}$ is the sum of the squared deviations.

In the ANOVA, $F$ ratio is commonly used to see which factor has a significant effect on the performance indicator. The $\mathrm{F}$ ratio is calculated from the statistical analysis and then compared

Table 8. Analysis of variance for $F_{c}$.

\begin{tabular}{lccccc}
\hline Source & Degree of freedom & Sum of squares & Mean squares & F ratio & Contribution (\%) \\
\hline A $(\mathrm{m} / \mathrm{s})$ & 3 & 30.34 & 10.11 & $4.74^{*}$ & 12.30 \\
$\mathrm{~B}(\mathrm{~cm} / \mathrm{min})$ & 3 & 15.73 & 5.24 & 2.46 & 6.38 \\
$\mathrm{C}(\mathrm{cm})$ & 3 & 173.82 & 57.94 & $27.15^{*}$ & 70.46 \\
$\mathrm{D}(\mathrm{ml} / \mathrm{s})$ & 3 & 20.37 & 6.79 & 3.18 & 8.26 \\
Error & 3 & 6.40 & 2.13 & & 2.60 \\
Total & 15 & 246.66 & & & 100 \\
\hline
\end{tabular}

* Significant at confidence level of 95\%. A: Peripheral speed, B: Traverse speed, C: Cut depth, D: Flow rate of cooling fluid. 


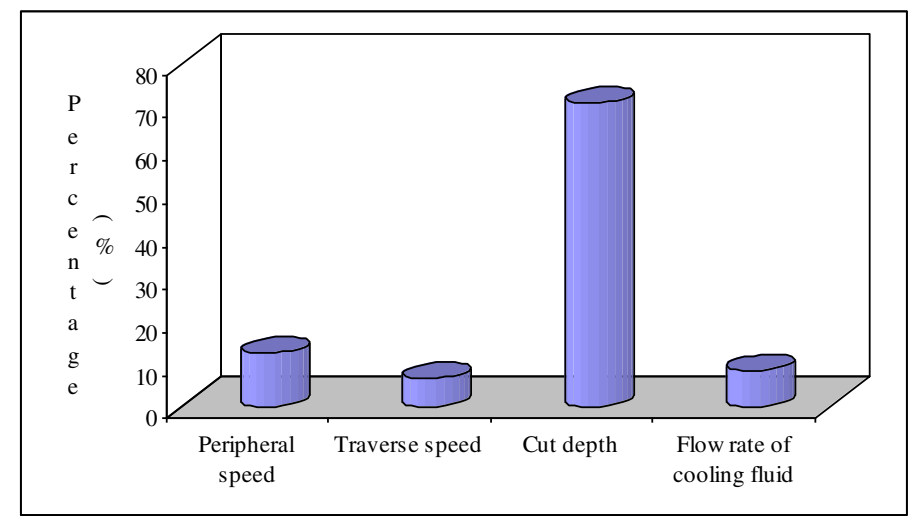

Figure 6. Variable percentage effect.

to the critical value. In performing the $F$ test, the mean of squared deviations $\mathrm{SS}_{m}$ due to each design parameter needs to be calculated. The mean of squared deviations $\mathrm{SS}_{m}$ is equal to the sum of squared deviations $\mathrm{SS}_{d}$ divided by the number of degrees of freedom associated with the design parameter (Yang \& Tarng 1998). If the $F_{\text {ratio }}$ calculated is larger than the $F_{\text {critical }}$ value, it is an indication that the statistical test is significant at the confidence level selected. If not, it indicates that the statistical test is not significant at the confidence level. In addition, the higher $F_{\text {ratio }}$ indicates that there is a considerable change on the performance characteristic due to the variation of the process parameters (Azmir \& Ahsan 2008). Table 8 shows the results of ANOVA carried out in the current study. Based on the ANOVA table, the cut depth and peripheral speed were statistically determined as the significant operating variables affecting the $\mathrm{F}_{c}$, while the others were statistically found insignificant since these operating variables could not pass the test. The percentage contributions of these operating variables are 70.46 and $12.30 \%$ for cut depth and peripheral speed, respectively. The contribution of each variable on the $\mathrm{F}_{c}$ is illustrated in figure 6.

\subsection{Confirmation tests}

As a final step in Taguchi method, the confirmation experiment is conducted for validation of the conclusions drawn during the analysis phase. The confirming experiments were conducted on the basis of optimum conditions of $\mathrm{A}_{4} \mathrm{~B}_{1} \mathrm{C}_{1} \mathrm{D}_{4}$ and the results were presented in table 9 . It was observed that the $\mathrm{S} / \mathrm{N}$ ratios obtained from the optimum conditions is bigger $(-30.86)$ than those in test $16(-33.65)$ where the maximum value of $\mathrm{S} / \mathrm{N}$ ratios among the 16 trials was produced. Accordingly, the $\mathrm{F}_{c}$ resulted from the optimum conditions is lower than that of test 16. In the relevant literature, $100 \mathrm{ml} / \mathrm{s}$ is the critical level for the flow rate of cooling fluid. When this value decreases, the chips produced may not be efficiently removed from the cutting area and this may lead to get higher cutting forces. Therefore, it is commonly recommended that the

Table 9. Results of confirmation test for optimization.

\begin{tabular}{lcccccc}
\hline & $\mathrm{A}(\mathrm{m} / \mathrm{s})$ & $\mathrm{B}(\mathrm{cm} / \mathrm{min})$ & $\mathrm{C}(\mathrm{cm})$ & $\mathrm{D}(\mathrm{ml} / \mathrm{s})$ & $\mathrm{F}_{\mathrm{c}}(\mathrm{N})$ & $\mathrm{S} / \mathrm{N}$ ratio \\
\hline Trial 16 & 40 & 70 & 0.5 & 150 & 48.11 & -33.65 \\
Optimal conditions & 40 & 40 & 0.5 & 200 & 45.32 & -30.86 \\
\hline
\end{tabular}


flow rate of cooling fluid must be above the critical values for achieving the effective cutting performances. When the optimum conditions are analysed, it is seen that the level of flow rate of cooling fluid increases from 150 to $200 \mathrm{ml} / \mathrm{s}$ indicating the value must be above the critical value for flow rate of cooling fluid. As a result, the results of confirmation experiment revealed that the $\mathrm{F}_{c}$ of the circular diamond sawblades in rock sawing could be improved through Taguchi approach.

\subsection{Prediction of the $F_{c}$ from operating variables}

To establish a prediction model, the statistical software package SPSS was used to perform the regression analysis using the experimental data in table 6 . In this analysis, the $\mathrm{F}_{c}$ and operating variables were considered as the dependent and independent variables, respectively. The regression model is given below (Eq. 19) and the dependent variable, the $\mathrm{F}_{c}$, is seen as a linear function of all operating variables. The determination coefficient $\left(\mathrm{R}^{2}\right)$ of the model is 0.92 . That means, $92 \%$ of the variation of the experimental data are explained by the equation.

$$
F_{c}(N)=88.294-3.536 A+1.530 B+71.461 C-0.221 D,
$$

where, $F_{C}$ is the cutting force $(\mathrm{N}), A$ is the peripheral speed $(\mathrm{m} / \mathrm{s}), B$ is the traverse speed $(\mathrm{cm} / \mathrm{min}), C$ is the cutting depth $(\mathrm{cm})$ and $D$ is the flow rate of cooling fluid $(\mathrm{ml} / \mathrm{s})$.

Validation of the model was carried out by considering the behaviour of $\mathrm{R}^{2}$, the $t$-and $F$-tests, the plots of observed vs. predicted $\mathrm{F}_{c}$, and the pattern of residuals. In the analysis, the $t$-test was used to examine the significance of each variable in the model, while the $F$-test was used for the whole model significance at a 95 per cent significance level. If the calculated $t$-value is larger than the tabulated $t$-value, the variable is considered to be significant. Similarly, if the calculated $F$ ratio is larger than the tabulated $F$-ratio, the model is considered to be significant again at a 95 per cent significance level. The statistical results of the model are given in table 10 in detail. As seen, the calculated $t$-values for the variables involved in the model and the calculated $F$-ratio for the model are larger than the tabulated $t$-value and $F$-ratio, respectively confirming the significance of the model. When the predicted trends vs. the observed trends were examined, it could be disclosed that there was a high degree of relationship between the predicted and observed $\mathrm{F}_{c}$ (see figure 7). In other words, the developed model can give adequate predictions for the $\mathrm{F}_{c}$ for the conditions. Pattern of residuals presented in figure 7, can provide the direct comparison of model and real data. In the present study, the residuals seem to be randomly scattered about the line (x-axis). That means, the correctness of the model was statistically confirmed. Furthermore, the $\mathrm{R}^{2}$ of the model is 0.92 indicating that the prediction model has a satisfactory goodness of fit.

Table 10. Statistical results of the regression model.

\begin{tabular}{|c|c|c|c|c|c|c|c|c|}
\hline $\begin{array}{l}\text { Independent } \\
\text { variables }\end{array}$ & Coefficient & $\begin{array}{l}\text { Standard } \\
\text { error }\end{array}$ & $\begin{array}{c}\text { Standard } \\
\text { error of } \\
\text { estimate }\end{array}$ & t-value & $\begin{array}{c}\text { Tabulated } \\
\text { t-value }\end{array}$ & F-ratio & $\begin{array}{l}\text { Tabulated } \\
\text { F-ratio }\end{array}$ & $\begin{array}{l}\text { Determination } \\
\text { coefficient }\left(\mathrm{R}^{2}\right)\end{array}$ \\
\hline Constant & 88.294 & 35.836 & 17.257 & & 2.464 & & & \\
\hline $\mathrm{A}(\mathrm{m} / \mathrm{s})$ & -3.536 & 0.772 & & -4.582 & & & & \\
\hline $\mathrm{B}(\mathrm{cm} / \mathrm{min})$ & 1.530 & 0.386 & & 3.965 & 1.75 & 32.648 & 3.28 & 0.92 \\
\hline $\mathrm{C}(\mathrm{cm})$ & 71.461 & 7.717 & & 9.260 & & & & \\
\hline $\mathrm{D}(\mathrm{ml} / \mathrm{s})$ & -0.221 & 0.077 & & $-2,854$ & & & & \\
\hline
\end{tabular}



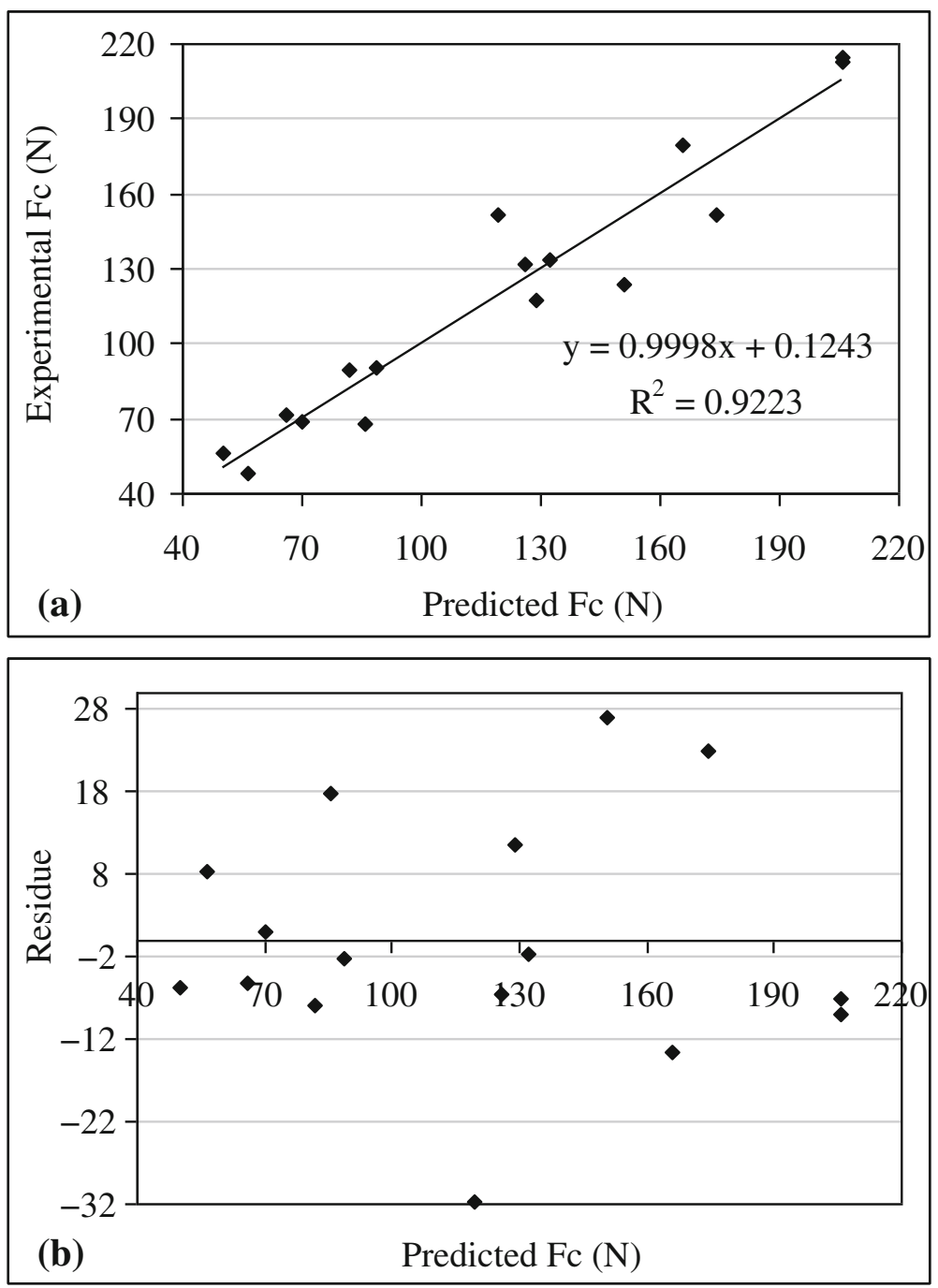

Figure 7. (a) Predicted $F_{c}$ derived from operation variables vs. experimental $F_{c}$; (b) the plots of the residue against the predicted $F_{c}$ values derived from the operating variables.

\section{Conclusions}

Using Taguchi method, the optimum conditions for obtaining minimum $\mathrm{F}_{c}$ were investigated for circular diamond sawblades in rock sawing. Most importantly, the current study examined the usability of Taguchi approach for the $\mathrm{F}_{c}$ optimization and prediction in circular sawing of rock. The results showed that the higher level of peripheral speed $(40 \mathrm{~m} / \mathrm{s})$, the lower level of traverse speed $(40 \mathrm{~cm} / \mathrm{min})$, the lower level of cut depth $(0.5 \mathrm{~cm})$ and the higher level flow rate of cooling fluid $(200 \mathrm{ml} / \mathrm{s})$ were determined as the optimum conditions minimizing the $\mathrm{F}_{c}$. The cut depth and peripheral speed were statistically determined as the most significant operating variables affecting $\mathrm{F}_{c}$, respectively. It was also disclosed that the proposed model can be used for the estimation of $\mathrm{F}_{c}$ in practical applications. In conclusion, the present study indicated that Taguchi 
approach is suitable for optimization of operating variables in rock sawing by circular diamond sawblades. Therefore, further studies aiming at optimization of other performance indicators of circular diamond sawblades in rock sawing such as specific energy, surface roughness and wear could be carried out by the Taguchi method.

\section{References}

Adnani A, Basri M, Abdul Malek E, Salleh A B, Abdul Rahman M B, Chaibakhsh N and Abdul Rahman R N Z A 2010 Optimization of lipase-catalyzed synthesis of xylitol ester by Taguchi robust design method. Ind. Crop. Prod., 31: 350-356

Aslantas K, Ozbek O, Ucun I and Buyuksagis I S 2009 Investigation of the effect of axial cutting force on circular diamond sawblade used in marble cutting process. Mater. Manufact. Process. 24: 1423-1430

Ataei M, Mikaeil R, Hoseinie H S and Hoseini M S 2012 Fuzzy analytical hierarchy process approachfor ranking the sawability of carbonate rock. Int. J. Rock Mech. Min. 50: 83-93

Atıc1 U and Ersoy A 2009 Correlation of specific energy of cutting saws and drilling bits with rock brittleness and destruction energy. J. Mater. Process. Technol. 209(13): 2602-2612

Aydin G, Karakurt I and Aydiner K 2013a Development of predictive models for specific energy of circular diamond sawblades in sawing of granitic rocks. Rock Mech. Rock Eng. 46(1): 767-783

Aydin G, Karakurt I and Aydiner K 2013b Wear performance of saw blades in processing of granitic rocks and development of models for wear estimation. Rock Mech. Rock Eng. 46(2): 1559-1575

Aydin G, Karakurt I and Aydiner K 2013c Investigation of the surface roughness of rocks sawn by diamond sawblades. Int. J. Rock Mech. Min. 61: 171-182

Azmir M A and Ahsan A K 2008 Investigation on Glass/Epoxy composite surfaces machined by abrasive waterjet machining. J. Mater. Process. Tech. 198: 122-128

Bayram F 2013 Prediction of sawing performance based on index properties of rocks. Arab. J. Geosci. 6: $4357-4362$

Buyuksagis I S 2010 The effects of circular sawblade diamond segment characteristics on marble processing performance. P. I. Mech. Eng. C-J. Mec. 224: 1559-156

Chou C S, Yang Y R, Chen H J and Chou W S 2010 The optimum conditions for preparing the lead-free piezoelectric ceramic of $\mathrm{Bi} 0.5 \mathrm{Na}^{2} .5 \mathrm{TiO}_{3}$ using the Taguchi method. Powder Technol. 199: 264-271

Engin C I, Bayram F and Yaşıtl E N 2013 Experimental and statistical evaluation of cutting methods in relation to specific energy and rock properties. Rock Mech. Rock Eng. 46: 755-766

Ersoy A, Buyuksagis I S and Atici U 2005 Wear characteristics of circular diamond saws in the cutting of different hard and abrasive rocks. Wear 258: 1422-1436

Ghani A J, Choudhury A I and Hassan H H 2004 Application of Taguchi method in the optimization of end milling parameters. J. Mater. Process. Technol. 145: 84-92

Guney A 2011 Performance prediction of large-diameter circular saws based on surface hardness tests for Mugla (Turkey) marbles. Rock Mech. Rock Eng. 44: 357-366

ISRM 1981 Rock characterization testing and monitoring suggested methods. In: E. T. Brown (Ed.), Oxford, UK: Pergamon Press, p. 211

Kahraman S and Gunaydin O 2008 Indentation hardness test to estimate the sawability of carbonate rocks. Bull. Eng. Geol. Environ. 67: 507-511

Karakurt I, Aydin G and Aydiner K 2012 An experimental study on the cut depth of the granite in abrasive waterjet cutting. Mater. Manufact. Process. 27(13): 538-544

Karakurt I, Aydin G and Aydiner K 2013a Experimental and statistical analysis of cutting force acting on diamond sawblade in sawing of granitic rocks. P. I. Mech. Eng. B-J. Eng. 227(2): 286-300

Karakurt I, Aydin G and Aydiner K 2013b Predictive modelling of noise level generated during sawing of rocks by circular diamond sawblades. Sadhana-Acad. P. Eng. 38(3): 491-511

Konstanty J 2002 Theoretical analysis of stone sawing with diamonds. J. Mater. Process. Technol. 123: $146-154$ 
Mikaeil R, Ataei M and Yousefi R 2013 Correlation of production rate of ornamental stone with rock brittleness indexes. Arab. J. Geosci. 6: 115-121

Mikaeil R, Yousefi R and Ataei M 2011 Sawability ranking of carbonate rock using fuzzy analytical hierarchy process and TOPSIS approaches. Sci. Iran. B. 18(13): 1106-1115

Nik G O, Sadrzadeh M and Kaliaguine S 2012 Surface grafting of FAU/EMT zeolite with (3aminopropyl)methyldiethoxysilane optimized using Taguchi experimental design. Chem. Eng. Res. Design. 90(5): 1313-1321

Sengun N and Altindağ R 2013 Prediction of specific energy of carbonate rock in industrial stones cutting process. Arab. J. Geosci. 6: 1183-1190

Tönshoff H K and Apmann H I 2002 Diamond tools for wire sawing metal components. Diam. Relat. Mater. 11(3-6): 742-74

Turchetta S 2012 Cutting force and diamond tool wear in stone machining. Int. J. Adv. Manufact. Technol. 61: 441-448

Ucun I, Aslantas K, Buyuksagis I S and Tasgetiren S 2011 An investigation on the effect of diamond concentration and matrix material composition in the circular sawing process of granites. P. I. Mech. Eng. C-J. Mec. 225: 17-27

Wang Y T and Huang Y C 2007 Improving forecasting performance by employing the Taguchi Method. Eur. J. Oper. Res. 176: 1052-1065

Yang H W and Tarng S Y 1998 Design optimization of cutting parameters for turning operations based on the Taguchi method. J. Mater. Process. Technol. 84: 122-129

Yaşıtlı E N, Bayram F, Unver B and Ozcelik Y 2012 Numerical modelling of circular sawing system using discrete element method. Int. J. Rock Mech. Min. 55: 86-96

Y1lmaz N G 2011 Abrasivity assessment of granitic building stones in relation to diamond tool wear rate using mineralogy-based rock hardness indexes. Rock Mech. Rock Eng. 44: 725-733

Y1lmaz N G, Goktan M R and Kibici Y 2011 An investigation of the petrographic and physico-mechanical properties of true granites influencing diamond tool wear performance and development of a new wear index. Wear 271(5-6): 960-969

Yousefi R, Mikaeil R and Abbasian R 2010 Study of factors Affecting on the sawability of the ornamental Stones. Proc. Int. Multidisciplinary Scientific GeoConference (SGEM), Varna, Bulgaria, 533-547 